\title{
Competitiveness of Indonesia's Cocoa Beans Export in the World Market
}

\author{
Amzul Rifin
}

\begin{abstract}
The objectives of this article is to analyze the competitiveness of Indonesia's cocoa beans export. Two analysis is conducted using revealed comparative advantage (RCA) and Almost Ideal Demand System (AIDS). The result indicates that Indonesia has comparative advantage in producing cocoa beans although the other three producing countries has higher RCA index. Meanwhile, Indonesia and Ghana's cocoa beans are complementary and increase in cocoa beans world demand will benefit Indonesia the most.
\end{abstract}

Index Terms-Cocoa beans, competitiveness, export, Indonesia

\section{INTRODUCTION}

Indonesia is the third largest producer of cocoa beans in the world with the estimated production of 450,000 tons in 2011/2012 [1]. The largest producer is Ivory Coast with 1.49 million tons of cocoa beans and the second is Ghana with 1.025 million tons of cocoa beans in the same year. In terms of growth during the period of 2005/2006 until 2011/2012, Indonesia's production suffered a decrease by an average of 3.16 percent; meanwhile Ivory Coast and Ghana have a positive production growth of 1.63 percent and 5.99 percent, respectively.

The cocoa beans is either consumed domestically or exported. In domestic market, the cocoa beans is processed into into intermediate products such as cocoa butter, paste or powder which will be utilized in the food or other industries. In 2010, the domestic consumption of cocoa beans reached 377,498 tons or 44.7 percent of cocoa beans production [2].

In terms of cocoa beans export, Indonesia exported 614 million US\$ or 6.7 percent of world total export in 2011. The largest is Ivory Coast with total export of 3 billion US\$, followed by Ghana with 2.07 billion US\$ and Nigeria with 959 million in 2011. Indonesia's cocoa beans export grew by 14.7 percent during the period of 2000 until 2011. In 2011, Indonesia's cocoa beans export decrease significantly by 48.4 percent mainly caused by the implementation of cocoa beans export tax in April 2010. Meanwhile Ivory Coast, Ghana and Nigeria grew with the average of 14.7, 29.4 and 15.5 percent during the same period (Fig. 1).

The fluctuative export value of the four largest exporters of cocoa beans indicates that exist competition between exporters in the world market. Therefore analyzing the competitiveness of Indonesia's cocoa beans export will be an important information especially in determining the marketing strategy in competiting with rival countries.

Manuscript received June 16, 2013; revised August 17, 2013.

Amzul Rifin is with the Department of Agribusiness, Faculty of Economics and Management, Bogor Agricultural University, Indonesia (e-mail: amzul_rifin@yahoo.com).

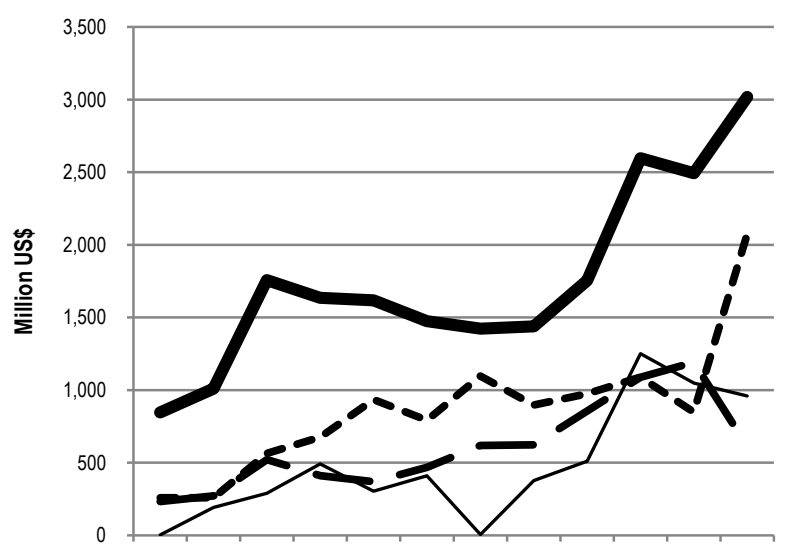

200020012002200320042005200620072008200920102011

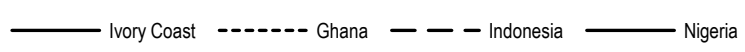

Fig. 1. Ivory coast, ghana, nigeria and indonesia's cocoa beans export, Souce: UN Comtrade, 2013.

In the case of cocoa beans in Indonesia, several articles have analyzed its compettiveness such as Widodo [3], Is [4], Rahmanu [5] and Lubis and Nuryanti [6]. These articles conclude that Indonesia cocoa beans export has comparative advantage in recentyears. Meanwhile Rifin and Nauly [7] assess the implementation of export tax to cocoa products export and concluded that the export tax decrease Indonesia's cocoa product competitiveness.

This article will analyze the competitiveness of Indonesia's cocoa beans export. In addition, competitivenss of Indonesia's competitor will also be calculated. With these information, marketing strategy will be constructed in order to compete with the other cocoa beans exporting countries.

\section{Methodology}

Two analysis is conducted in order to analysis the competitiveness of Indonesia's cocoa beans export. First using the revealed comparative advantage (RCA) proposed by Balassa [8]. A country which possess a comparative advantage in producing a particular commodity over another country means that this country produce the product at lower opportunity costs than the other country. Balassa suggest the revealed comparative advantage (RCA) in measuring the comparative advantage since the trade pattern reflected or revealed the comparative advantage. The formula is as follows:

$$
R C A=\frac{X_{i j} / X_{i}}{X_{w j} / X_{w}}
$$


where $X_{i j}$, value of country $i$ 's export of commodity $j ; X i$, value of country $i$ 's total exports; $X w j$, value of world exports of commodity $j ; X w$, value of world exports.

The RCA index shows the extent of commodity specialization in a country's exportsrelative to the share of that commodity in world exports. A high value indicatescomparative advantage of a country in the production of a particular good. Whenthe RCA index of a country is greater than 1 , this means that the share ofthat commodity in the country's exports is higher than the world's average and the country has a comparative advantage on the product. Meanwhile when the RCA is less than 1, it means that the country has no comparative advantage on the product.

The second analysis is using Almost Ideal Demand System (AIDS) which was introduced by Deaton and Muellbauer [9] for analyzing demand analysis. Several years later, Winters [10] utilized the approach for analyzing the import demand which analyze competition between different importing countries in a specific market/country for the same product. The AIDS model has been used extensively in applied demand analysis in recent years because of its theoretical consistency and functional flexibility (Chang and Nguyen) [11]. The model used is as follows:

$$
S_{i}=\beta_{i} \ln \left(\frac{M}{P}\right)+\sum_{i=1}^{n} \gamma_{i j} \ln P_{j}+\varepsilon_{t}
$$

where $S$ = share of import source in the world market; $P=$ price of cocoa beans (US $\$ /$ ton) and $M=$ expenditure.

The theoretical restrictions of adding up, homogeneity and symmetry hold if the parameters satisfy the corresponding expressions:

$$
\text { Adding up: } \sum_{i=1}^{n} a_{i}=1, \sum_{i=1}^{n} r_{i j}=0, \sum_{i=1}^{n} \beta_{i}=0
$$

Homogeneity: $\sum_{i-1}^{n} r_{i j}=0$, Symmetry: $r_{i j}=r_{j i}$

Compensated and uncompensated price elasticities will be calculated. The compensated (or Hicksian) price elasticity represents only the price effect of a change in price and it is compensated for the change in income, meanwhile uncompensated (or Marshallian) price elasticity contains the price and income effect of a change in price. The compensated $\left(\eta_{i j}^{*}\right)$, uncompensated price elasticities $\left(\eta_{i j}\right)$ and expenditure elasticities $\left(\mu_{i}\right)$ are calculated as follows:

$$
\begin{gathered}
\eta_{i j}^{*}=-\delta_{i j}+\frac{\gamma_{i j}}{S_{i}}+S_{j} \quad \eta_{i j}=-\delta_{i j}+\frac{r_{i j}-\beta_{i} S_{j}}{S_{i}} \\
\mu_{i}=1+\frac{\beta_{i}}{S_{i}}
\end{gathered}
$$

where $\boldsymbol{\delta}_{i j}$ is the Kronecker delta, when $i=j$ the value of the Kronecker delta is 1 meanwhile when $i \neq j$ the value is 0 .

The data used in this study is annual data from 1967 to 2011. The source of the data is from the UN Comtrade using the SITC Revision 1 with the four digit code of 0721 which represents the cocoa beans.
For the RCA calculation, besides Indonesia three other countries will also be calculated: Ivory Coast, Ghana and Nigeria. Meanwhile in AIDS model, four equation will also be calculated: Ivory Coast, Ghana, Indonesia and Nigeria which represents the largest cocoa beans exporting countries in 2011.

\section{RESULTS AND DISCUSSION}

The first analysis is using the revealed comparative advantage (RCA), the index indicates that until 1982 Indonesia has no comparative advantage in producing cocoa beans but onwards it has comparative advantage shown by the RCA value more than 1 (Fig. 2). The highest values was achieved in 2006 with the RCA index of 16.96 meanwhile in 2011 it dropped significantly to 5.54 caused by the decrease in cocoa beans export significantly. During 1967-2011 the average RCA index is 6.14 .

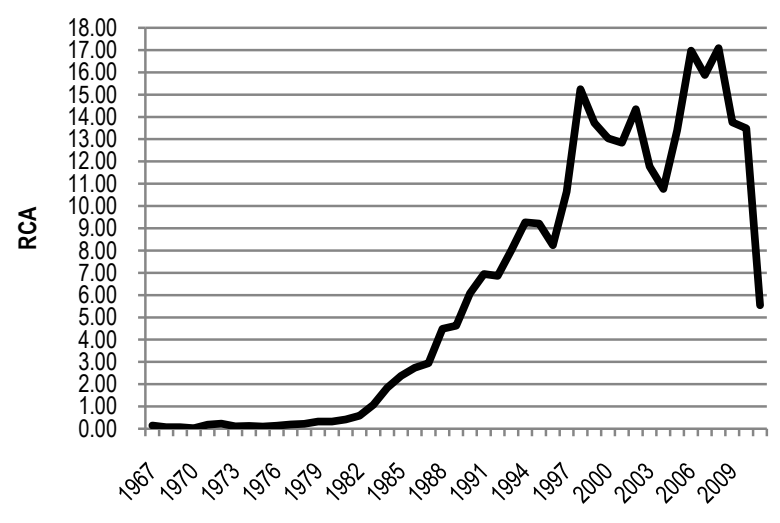

Fig. 2. Indonesia's RCA index, 1967-2011.

Comparing with the other three cocoa beans producing countries, Indonesia's RCA is much smaller. During the period of 1967-2011, Ivory Coast, Ghana and Nigeria's average RCA reached 339.66, 528.92 and 24.00, respectively (Fig. 3). The high RCA for these three countries mainly caused by the fact that cocoa beans is the main export commodities of these countries. For Ivory Coast, cocoa beans export in average from 1967-2011 contributed 24.52 percent of its total export, meanwhile Ghana 45.89 percent and Nigeria 3.74 percent. On the other hand, contribution of cocoa beans to Indonesia's total export in average is 0.34 percent during the same period.

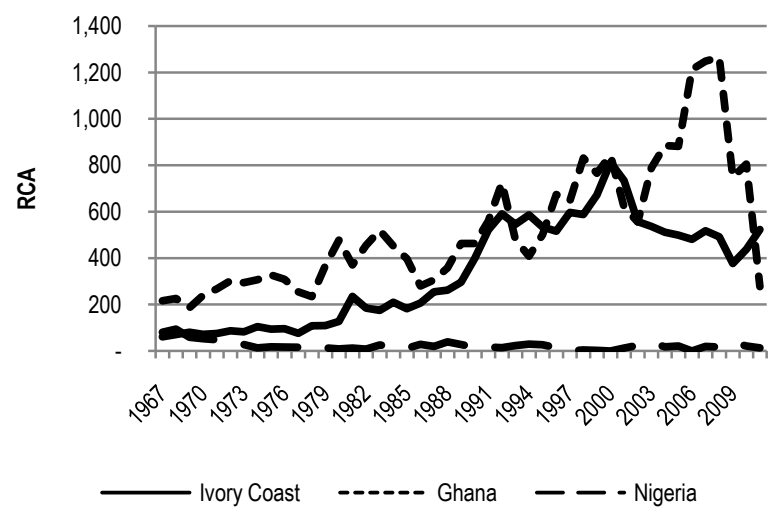

Fig. 3. Ivory coast, ghana and nigeria RCA index, 1967-2011. 
The second analysis is using the Almost Ideal Demand System (AIDS) approach. In this approach the competition between cocoa beans exporter can be analyzed. The equation coefficients is shown in Table I which is used in calculating elasticities in Table II.

TABLE I: ESTIMATION RESULT

\begin{tabular}{|c|c|c|c|c|}
\hline \multirow[b]{2}{*}{ Variables } & \multicolumn{4}{|c|}{ Equation } \\
\hline & $\begin{array}{l}\text { Ivory } \\
\text { Coast }\end{array}$ & Ghana & Indonesia & Nigeria \\
\hline Price Iv Coast & $-0.270^{* * *}$ & 0.061 & -0.010 & $0.127^{* * * *}$ \\
\hline Price Ghana & 0.061 & 0.061 & $-0.048^{* *}$ & -0.029 \\
\hline Price & -0.010 & $-0.048^{* *}$ & 0.016 & -0.005 \\
\hline $\begin{array}{l}\text { Indonesia } \\
\text { Price Nigeria }\end{array}$ & $0.127^{* * *}$ & -0.029 & -0.005 & $-0.042^{*}$ \\
\hline Price ROW & $0.091^{* * * *}$ & $-0.045^{* * *}$ & $0.048^{* * *}$ & $-0.051^{* * *}$ \\
\hline Expenditure & 0.008 & $0.028^{* * *}$ & $0.032^{* * *}$ & $0.017^{*}$ \\
\hline Constant & -0.456 & 0.139 & $-0.681^{* * * *}$ & 0.261 \\
\hline $\mathrm{R}^{2}$ & 0.379 & 0.341 & 0.651 & 0.468 \\
\hline$\chi^{2}$ & $36.69^{* * *}$ & $30.83^{* * *}$ & $82.18^{* * *}$ & $43.04^{* * *}$ \\
\hline $\begin{array}{c}{ }^{* * * *} \text { signif } \\
\text { signifi } \\
{ }^{*} \text { significa }\end{array}$ & $\begin{array}{l}\text { at } 1 \% 1 \\
\text { at } 5 \% \text { le } \\
10 \% \text { le }\end{array}$ & & & \\
\hline
\end{tabular}

TABLE II: ELASTICITIES ESTIMATION

\begin{tabular}{|c|c|c|c|c|}
\hline \multirow[b]{2}{*}{ Elasticities } & \multicolumn{4}{|c|}{ Countries } \\
\hline & $\begin{array}{l}\text { Ivory } \\
\text { Coast }\end{array}$ & Ghana & Indonesia & Nigeria \\
\hline \multicolumn{5}{|l|}{ Price } \\
\hline \multicolumn{5}{|l|}{ Compensated } \\
\hline Price Iv Coast & $-1.584^{* * *}$ & $0.611^{* * *}$ & $0.126^{*}$ & $0.539^{* * *}$ \\
\hline Price Ghana & $0.400^{* * *}$ & $-0.495^{* * *}$ & -0.634 & -0.043 \\
\hline Price Indonesia & -0.024 & $-0.183^{* *}$ & $-0.669^{* * *}$ & 0.015 \\
\hline Price Nigeria & $0.539^{* * *}$ & -0.026 & 0.032 & $-1.223^{* * *}$ \\
\hline Price ROW & $0.621^{* * * *}$ & $0.094^{* * *}$ & $1.144^{* * *}$ & $-0.105^{* * *}$ \\
\hline \multicolumn{5}{|l|}{ Uncompensated } \\
\hline Price Iv Coast & $-1.896^{* * *}$ & 0.264 & -0.345 & $-1.008^{* * *}$ \\
\hline Price Ghana & 0.196 & $-0.722^{* * *}$ & -0.942 & $-0.271^{*}$ \\
\hline Price Indonesia & -0.035 & $-0.249^{* * * *}$ & $-0.758^{* * *}$ & -0.050 \\
\hline Price Nigeria & 0.415 & -0.164 & -0.155 & -1.362 \\
\hline Price ROW & $0.294^{* * *}$ & $-0.270^{* * * *}$ & 0.651 & $-0.469^{* *}$ \\
\hline Expenditure & $1.026^{* * *}$ & $1.143^{* * *}$ & $1.549^{* * *}$ & $1.144^{* * *}$ \\
\hline
\end{tabular}

The results indicate that Indonesia's cocoa beans is inelastic, either in compensated or uncompensated elasticities, which means it is not sensitive to price changes. Meanwhile cocoa beans from Ivory Coast and Nigeria is elastic and Ghana inelastic. The inelastic elasticities inferred that in order to increase export revenue is by increasing export quantity not price decrease or discount.

Regarding competition with other countries cocoa beans, Indonesia cocoa beans has complementary relation with Ghana indicated by the negative cross price elasticities meanwhile with Ivory Coast and Nigeria can not be concluded since the elasticities is not significant. The complementary relation can be explained by the fact that Indonesia mostly exported in the form of unfermented beans meanwhile Ghana mostly in the fermented beans form. In making the processed cocoa product, this two forms of beans is mixed. In addition, cocoa beans exported from Ivory Coast and Ghana substitute with each other shown by the positive cross price elasticities. This is because both countries mainly exported in the fermented form.

The expenditure elasticities indicates that Indonesia has the highest value compare to the other three countries. This means that increase in world demand of cocoa beans will benefit Indonesia more rather than the other countries.

\section{CONCLUSION}

Indonesia has a comparative advantage on producing cocoa beans but the other producing countries, Ivory Coast, Ghana and Nigeria, has also comparative advantage in producing cocoa beans and their RCA index is several times higher than Indonesia.

Indonesia and Ghana's cocoa beans are complementary in the international market therefore cooperation between the two countries is recommended. Increase in cocoa beans world demand will benefit Indonesia the most.

\section{REFERENCES}

[1] ICCO Annual Report 2012/2013, International Cocoa Organization, 2013.

[2] Revitalization progress of Cocoa's Industry in Indonesia, Media Data Riset, Jun. 2011.

[3] L. Widodo, "Indonesia's cocoa and processed cocoa competitiveness," MS Thesis, University of Indonesia, Depok, Indonesia, 2000.

[4] I. Is, "Indonesia's cocoa competitiveness in international market," B.S. Thesis, Bogor Agricultural University, 2008.

[5] R. Rahmanu, "Indonesia's cocoa processed industry competitiveness," BS Thesis, Bogor Agricultural University, 2009.

[6] A. Lubis and S. Nuryanti, "The Impact of ACFTA and Cocoa Trade Policy in Domestic and China Market," Analisis Kebijakan Perdagangan, vol. 9, pp. 143-156, Jun. 2011.

[7] A. Rifin and D. Nauly, "The effect of export tax on indonesia's cocoa export competitiveness," presented at the 57th Australian Argicultural and Resource Economics Society (AARES), Sydney, Australia, 5-8 February 2013.

[8] B. Balassa and Bela, "Trade liberalization and revealed comparative advantage," ManchesterSchool of Economics and Statistics, vol. 33, pp. 99-124, Jun.1965.

[9] A. Deaton and J. Muellbauer, “An almost ideal demand system,"American Economic Review, vol. 70, pp. 312-325, Sep. 1980.

[10] L. A.Winters, "Separability and the specification of foreign trade functions," Journal of International Economics, vol. 17, pp. 239-263, Sept. 1984.

[11] H. Chang and C. Nguyen,"Elasticity of demand for Australian cotton in Japan," The Australian Journal of Agricultural and Resource Economics, vol. 46, pp. 99-113, Jan 2002.

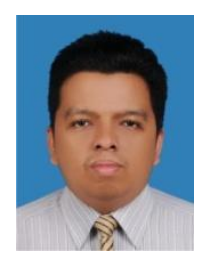

Amzul Rifin was born in Bogor, Indonesia on September 21, 1975. He earned B.Sc. degree in Agribusiness from Bogor Agricultural University in 1998, MA in International Development Program from International University of Japan in 2005 and Ph.D. degree in Agricultural and Resource Economics from The University of Tokyo, Japanin 2011. He has been working in Bogor Agricultural University as lecturer since 1998. He has published several journal articles concerning Indonesia's palm oil international trade.

Dr. Rifin is a member of Indonesia's Agricultural Economists Association (Perhepi) and Indonesia's Regional Science Association (IRSA). 